\title{
AVRUPA BIRLIĞI'NDE EURO KRIZI VE TÜRKIYE EKONOMISINE ETKILERI
}

Şahap KAVCIOĞLU*

\section{öz}

Ortak para birimine geçişte Maastricht kriterlerinin göz ardı edilmesi sonucunda, kriterleri sağlamayan ülkelerin borç yükleri ve kamu açıkları artmışıır. 2008 yılında meydana gelen küresel

Dr., T. Halk Bankası A.Ş., Kredi Politikaları Genel Müdür Yardımcısı, sahap.kavcioglu@halkbank.com.tr. 
krizin de etkisi ile bu ülkelerdeki borç yükleri ve kamu açıkları sürdürülemez hale gelmiş ve Avrupa'da Euro krizi patlak vermiştir. Dünya ülkeleri arasındaki finansal entegrasyon nedeniyle, ülkemizde Euro krizinden etkilenmiş ve etkilenmeye devam etmektedir. Bu çalışmamızı da Euro krizinin çıkmasındaki nedenler, gelişimi ve ekonomimiz üzerindeki mevcut ve olası etkilerine yönelik bir değerlendirme ortaya koyulmaya çalışılmışıır.

Anahtar Kelimeler: "Avrupa Birliği", "Avro Krizi", "Avrupa Birliği Ortak Para Birimi (Euro)", "Türkiye Ekonomisi".

\section{ABSTRACT}

While the process of entering Eurozone, the countries which ignore Maastricht criteries are faced with increased debt burdens and public deficit. Because of a global crise happened in 2008, the debt burdens and public deficits became unsustainable in this countries and Euro crise blowed up. Because of a financial integration between countries, our country also effected and still it is being affected from this Euro crise. With this study, it is aimed to reveal an assessment of the reasons underlying the Euro crisis, its expansion and its current and possible effects over our economy.

Keywords: "European Union", "Euro Crisis", "European Union's Common Currency (Euro)", "Turkey's Economy".

\section{Giriş}

1970'lerde başlayan finansal liberalleşme süreci, uluslararası finansal piyasalar arasındaki engellerin kalkmasına neden olmuştur. Finansal piyasaların arasındaki engellerin kalkması ile birçok ülkenin sermaye hesabı bu dönemde dışa açık hale gelmiştir. Bu dönemde artan uluslar arası sermaye daha hızlı yaylan finansal krizleri de beraberinde getirmiştir. DELiCE (2003). ABD'nin dördüncü büyük yatırım bankası olan Lehman Brothers'ın, 2008 ylında iflas etmesiyle patlak veren kriz de bu krizlere örnek teşkil etmiştir. Kısa sürede tüm dünyaya yayılarak 
küresel çapta bir mali ve reel sektör krizine dönüşen bu kriz, $A B$ ülkelerinde de kamu açıkları ve borç stoklarının ciddi boyutlarda artmasına ve birçok üye ülkede kamu maliyesinin sürdürülebilirliğinin tehlikeye girmesine neden olmuştur. TC Başbakanlık AB Genel Sekreterliği (2011).

Avro bölgesine üye ülkelerde ortak para birimi kullanılmasının yanı sıra, bu ülkelerde para politikası ortak bir merkez bankası aracilığıyla yürütülmektedir. Bu durumun nedeniyle ekonomik entegrasyon avro bölgesi ülkelerinde ileri düzeylere ulaşmış ve bu ülkelerin birinde yaşanan ekonomik durum tüm bölgeyi etkiler hale gelmiştir. $A B$ ve özellikle de avro bölgesindeki bazı ülkeler 2008 ylında patlak veren küresel krizle birlikte, aşırı borçlanma ve standartların üzerinde yaşam nedeniyle mali sıkıntılarla karsı karsıya kalmışlardır. SANDOVAL ve DiĞERLERi (2011). Özellikle Yunanistan, İlanda, Portekiz, İspanya ve italya bu krizin derinleştiği $A B$ üyesi ülkeler olurken, uluslararası piyasalarda ekonomik entegrasyon nedeniyle $A B$ ülkelerinin tamamının krize gireceği beklentileri oluşmuştur. Nitekim 2010 yllında Yunanistan'da giderek derinleşen borç krizi, ülke sınırlarını aşarak tüm avro bölgesini etkisi altına almış ve avro bölgesi borç krizi olarak adlandırlmaya başlanmıştır. AKÇAY (2012).

Çalışmanın amacl; 2008 ylında ABD'de patlak veren küresel krizin avro bölgesi üzerindeki etkileri, avro krizinin çıkmasındaki nedenler, bu krizin gelişimini değerlendirmek ve avro krizinin Türkiye ekonomisi üzerindeki mevcut ve olası etkilerine yönelik bir değerlendirme ortaya koymaktır.

\section{Avrupa Birliği ve Euro Krizi}

Avrupa kıtasında bütünleşme düşüncesi çok eski tarihlere dayanmakla birlikte, özellikle II. Dünya savaşının sona ermesiyle bu konuda birçok adım atılmışır. Fransa, Almanya, İtalya, Hollanda, Lüksemburg ve Belçika 1951 yllında bu konudaki en somut adımı atarak 1951 yllında Avrupa Kömür ve Çelik Topluluğu (AKÇT) kurmuşlardır. AKÇT'nin kurulmasından sonra göstermiş olduğu başarılı gelişme, Avrupa'da daha geniş kapsamlı bir 
ekonomik birleşmenin gerçekleştirilmesine yönelik yeni görüşleri de beraberinde getirmiştir. Özellikle ekonomik bütünleşme üzerine yoğunlaşan bu görüşler, Messina'da düzenlenen konferansta iki yeni Avrupa Topluluğu'nun daha kurulması yönünde karar alınmasını sağlamıştır. Bu konferanstan sonra 25 Mart 1957'de Roma'da imzalanan antlaşma ile Avrupa Atom Enerjisi Topluluğu (EURATOM) ve Avrupa Ekonomik Topluluğu (AET) kurulmuştur. KUTLU (2007).

Bu anlaşma ile üye ülkeler, üretim faktörlerinin serbest dolaşımını, ortak politikaların oluşturulmasını ve ekonomik anlamda entegrasyonu sağlayacak olan dış ticaret ve sermaye hareketlerinin serbestleştirilmesini hedeflemişlerdir. Hedeflenen amaçlara ulaşılması ilk etapta sınırlı kalmış, ancak 1986 yılında ülkeler arasında var olan fiziki, teknik ve mali engellerin kaldırılarak iç pazarın bütünleştirilmesi konusunda somut adımlar atımış ve hedefe ulaşımıştır. 1992 yılında bu ülkeler, Avrupa Birliği anlaşması olarak da bilinen Maastricht Anlaşmasını imzalamışlardır. Ekonomik ve Parasal Birlik (EPB) amacının hedef konulduğu bu anlaşma aynı zamanda resmen Avrupa Birliğinin (AB) kuruluş tarihi sayılmıştır.

\section{Grafik 1: 2012 Yılı İtibariyle Bütçe Açığı/GSYH (\%)}

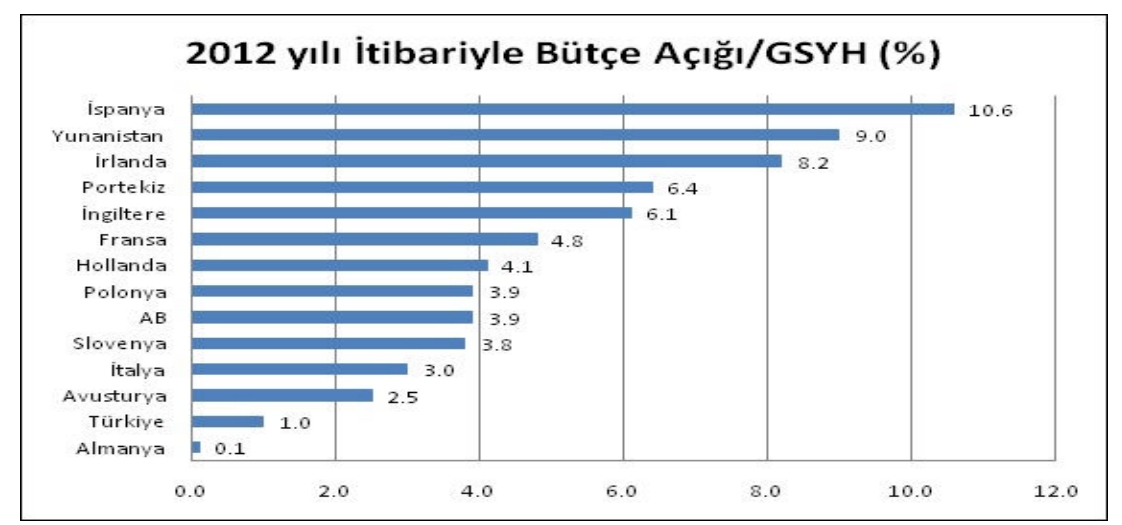

Kaynak: Eurostat, Hazine Müsteşarlığı

1 Kasım 1993'de yürürlüğe giren Maastricht Antlaşması'nda, ekonomik ve parasal birliğin aşamaları, izlenecek eko- 
nomik ve parasal politikalar ve bu politikaların uygulanması için gerekli kurumsal değişiklikler ayrıntılı olarak düzenlenmiştir. Ekonomik ve Parasal birliğin gerçekleştirilmesi doğrultusunda, üye ülke ekonomileri arasındaki farkılıkların giderilebilmesi açısından, "Maastricht Kriterleri" olarak adlandırlan yakınlaşma kriterleri tespit edilmiştir. Özellikle tek bir para kullanımı için önem arz eden söz konusu kriterler aşağıda yer almaktadır:

- Üye ülkelerin kamu açıklarının GSYiH'lerine oranı \%3'ü geçmemelidir.

- Üye devletlerin kamu borçlarının GSYiH'lerine oranı \%60'ı geçmemelidir.

- Üye ülkelerde uygulanan uzun vadeli faiz oranları, 12 aylık dönem itibarıyla, fiyat istikrarı bakımından en iyi performansa sahip 3 ülkenin faiz oranını 2 puandan fazla aşmamalıdır.

- Son 2 yll itibarıyla, bir üye ülkenin para birimi, diğer bir üye ülkenin para birimi karşısında devalüe edilmemiş olmalıdır.

- Toplulukta fiyat istikrarı bakımından en iyi performansa sahip üç ülkenin ylllık enflasyon oranları ortalaması ile, bir üye ülkenin enflasyon oranı arasındaki fark 1,5 puanı geçmemelidir. DiLEKLI ve YEŞiLKAYA (2002).

Maastricht kriterlerine uyum sağlamak ciddi çabalar gerektirmekle birlikte, bu konuda önder ülkeler bile bu kriterlerden uzak kalabilmektedir. Nitekim şekil 1 ve 2'de 2012 yll itibariyle ortak para birimi kullanan ülkelerin ağırıkklı kısmının, Maastrict kriterlerinin ilk 2'sinin dışında oldukları görülmektedir. Şekil l'de ortak para birimi kullanan ülkelerde kamu açıkları/GSYH oranları görülmektedir. Buna göre 2012 ylında Almanya dışında ilgili kritere uyum sağlayan Euro ülkesi bulunmamakla beraber, ülkemizde bu oranın \% 1 ile ilgili kritere uygun olduğu görülmektedir.

Avro bölgesi ülkelerinde ve Türkiye'de Kamu borç/GSYH oranının görüldüğü Şekil 2'ye göre, Slovenya ve Polonya dışın- 
daki avro bölgesi ülkelerinin \% 60 olan Maastricht kriterine uyum sağlamadıkları görülmektedir. Aynı şekilde ülkemizin Kamu borç/GSYH oranı da görülmekte olup, en fazla \% 60 olarak belirlenen Maastricht kriterine uyumlu olduğu görülmektedir.

Grafik 2: 2012 Yılı İtibariyle Kamu Borç/GSYH (\%)

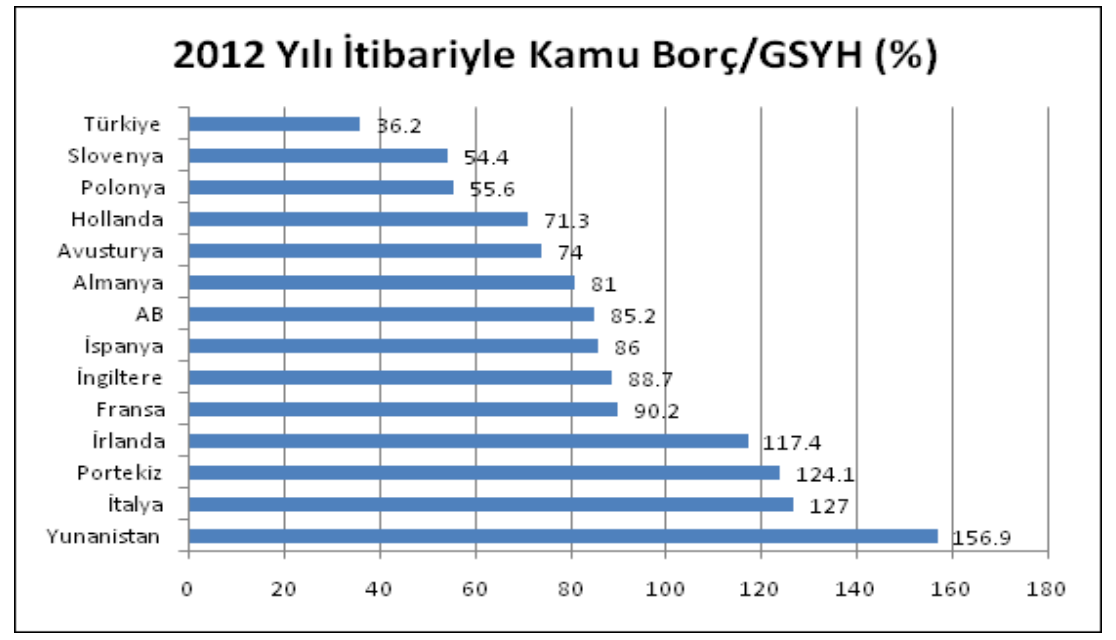

Kaynak: Eurostat, Hazine Müsteşarlığı

Maastricht kriterlerini sağlayarak ortak paraya geçen Avrupa ülkeleri, düşük enflasyon ve istikrarlı bir büyüme ile güvenli, uzun dönemli programlar yapabilmeyi amaçlamışlardır. Para birliği öncesinde içe dönük ve önceki dönemlerin etkisiyle plan yapan ülkeler, ortak para ile daha dışa dönük, yeni imkânlar araştıran, daha büyük bir pazar için ileriye yönelik program yapan dolayısıyla daha verimli ve rekabetçi ülkeler olmayı hedeflemişlerdir. Nitekim temelleri 1993 yllında yürürlüğe giren Maastrictcht Antlaşması ile atılan parasal birlik sürecinde, 1999 ve 2002 yılları arasında önemli bir aşama kaydedilerek tek paraya (EURO) geçilmiştir. ÖZBAY (1997).

Avrupa Birliği ülkelerinde ekonomik bütünleşmeyi sağlamak adına başlatılan süreç, ortak para birimi olan Euro ile birlikte hedeflerine de ulaşmıştır. Ancak belirlenen hedeflere ulaşilırken, $A B^{\prime}$ nin bu amaçlarının istenilen sonuçlar doğurup doğur- 
mayacağı konusu tartışılmaya başlanmıştır. Özellikle, Yunanistan, İtalya, İspanya, Portekiz, İrlanda ve Güney Kıbrıs gibi ülkelerde görülen makro ekonomik dengesizlikler bu tartışmaların gündemde kalmasına neden olmaktadır. Bu ülkelerde yaşanan ekonomik krizlerin yükünü sadece kendileri değil birlik ülkeleri çekmekte ve bu entegrasyon tüm dünya ekonomisini etkilemektedir.

Tarihsel süreçte özellikle finansal merkezlerde ortaya çıkan finansal kriz dalgasını, borç krizleri izlemiştir. HILSENRANTH (2010). ABD'de konut piyasasında hızla büyüyen spekülatif balonunun patlamasıyla ortaya çıkan kriz, 2008'in ikinci yarısından itibaren bankacılık ve sigortacılık sektörlerini, yatırımları ve ticareti etkileyerek, küresel finansal krize dönüşmüştür. Eylül 2008'den itibaren sok dalgaları ticaret ve finans kanallarından tüm dünyaya yayılmış, kriz tüm dünya ülkelerini etkilediği gibi $A B$ ülkelerini de etkilemiştir. KILIÇ ve BAYAR (2012).

Küresel finansal krize borç krizleri ile tepki veren Euro bölgesi ülkeleri, ağır borçlanma nedeniyle mali sıkıntılarla karsı karsıya kalmışlardır. SANDOVAL ve DiĞERLERi (2011). Özellikle, Yunanistan, İtalya, İspanya, Portekiz, İlanda ve Güney Kıbrıs gibi ülkelerin kamu borçlarının sürdürülemez boyutlara ulaşması, Euro krizinin patlak vermesi ve devam etmesine neden olmuştur.

\section{Euro Krizinin Gelişimine İlişkin Bir Değerlendirme}

Avrupa Birliği'nde ortak bir para birimi kullanmanın esas amacl, kur ve faiz risklerini azaltarak birlik içindeki ticareti ve bütünleşmeyi geliştirmekti. Avrupa Birliği'nde gelişen ticaretle birlikte, birliğin nispeten refah düzeyi düşük ülkelerinin refah düzeyi artacak ve bu ülkeler üretim gücü yüksek ülkeler için önemli bir pazar olacaktı. Bu süreçle beraber, birliğe üye olan ve Euro para birimine geçen ülkelerden İrlanda, Portekiz, Italya, İspanya, Yunanistan ve Güney Kıbrıs gibi ülkelerin hızla milli gelir düzeyleri ve dolayısıyla refah seviyeleri artmıştır. Üretim gücü yüksek ülkelerin pazarı haline gelen bu ülkelerin cari açıkları ise refah dü- 
zeylerine paralel bir seyir izlemiş ve sürdürülemez seviyelere gelmiştir.

Ortak para birimi kullanan ülkelere Maastricht kriterleri bakıldığında, üye ülkelerin büyük çoğunlukla bu kriterlere uygun oldukları görülmektedir. Kriterlerin tamamına uyum sağlamayan ülke olmamakla birlikte, başlangıçta istisnalar olduğu gibi Euro'ya geçişle birlikte kriterlerin dışına çıkan ülkelerde olmuştur. Bu kriterler arasında finansal krizlerin en önemli sebeplerinde biri olan cari açık ile ilgili bir kriterin olmaması dikkat çekicidir ki, bu durum Euro krizinin de en önemli sebebi olarak görülmektedir.

Euro krizine bakıldığında, bu krizin başlangıcını 2008 ylı küresel krizden ayrı tutmamak gerekir. 2008 ylında dünyayı saran ve 2009 yllında etkisini artıran küresel kriz, yapılan düzenlemelere rağmen Avrupa birliği üyesi birçok ülkeyi iflasın eşiğine getirmiştir. Küresel krize dayanamayıp iflasın eşiğine gelen Letonya ekonomisi, EURO krizinin başlangıcı niteliğindedir. Avrupa birliğinin motoru niteliğindeki Almanya ve Fransa bu ülkeye yardım ellerini uzatırken, Macaristan, Polonya, Romanya, Bulgaristan, Litvanya gibi diğer Avrupa birliği ülkelerinin de sürece katılması, birlik için patlak verecek krizlerin habercisi olmuştur. Öyle ki küresel krizin patlak verdiği $A B D$, bu süreçte aldığı önlemler ve yarattığı fonlarla krizin etkisini atlatmaya başlamış ancak, Avrupa'da giderek artan sorunların baş göstermesi yeni bir krizin dillendirilmesine neden olmuştur.

Euro krizi, 2009 yllı sonlarında dillendirilmeye başladıktan sonra, bölgede yer alan bazı ülkelerde yaşanan ciddi borç yükü artışlarıyla yeni bir kriz olarak patlak vermiştir. Euro krizinde kıvılcımı yakan írlanda'da yaşanan ekonomik kriz olurken, bu krizi sırasıyla Portekiz, Yunanistan ve yeni patlak veren Güney Kıbrıs krizleri izlemiştir. Avrupa birliğinin geleceğinin sorgulanmasına neden olan ve henüz çözüme kavuşturulamayan Yunanistan krizi, Euro krizinin en sıkıntılı kısmı olarak gösterilmekteyken, patlak veren Güney Kıbrıs krizi ile birlikte Avrupa Birliği'nin geleceği konusundaki tartışmalarda artmıştır. 
Krizin en önemli ayaklarından olan Yunanistan krizinin nedenlerine bakarken, ülkenin birliğe üye olduğu dönemlere kadar inmek gerekmektedir. 2005 ylında Euro' ya geçerken Yunanistan'a uygulanan kurlar, ülkenin ulusal parasını aşırı değerli kılmıştır. Bu durum ülke ekonomisinin rekabet gücünü daha Euro' ya geçiş anında Almanya gibi birliğin üretici ülkelerinin gerisine düşürmüştür. Ülkede enflasyon artmış, fiyatlar Almanya'nın iki kat üzerine çıkmıştır. Ayrıca Euro'nun bu dönemde dolara karşı pahalılaşması, Yunanistan'ın rekabet gücünü sadece birlik ülkelerine karşı değil, aynı zamanda bölge dışı ülkelere karşı da zayıflatmış̧ır. Bu sürecin doğal sonucu olarak Yunanistan'da dış açıklar artmış, cari açık sürdürülemez boyutlara ulaşmıştır.

Yunanistan gibi üretim seviyesinin düşük olduğu ülkelerde, ekonomide canlanma ve büyüme ülkeye gelen büyük kaynaklar sayesinde olmaktadır. Zamanla kaynak aktarımının geri dönme aşaması gelir ve dış kaynakların ülkeye girişi yavaşlar. Sonuçta dış açıklar finanse edilemez ve süreç ekonominin finansal krize girmesi ile sonuçlanır.

Yunanistan'da da bu dönemde yukarıdaki sürece çok yakın bir süreç görülmüştür. Ülkenin dış açıkları artmış, cari açıkları rekor seviyelere ulaşmış, ülkeye sürekli sıcak para girişi olmuştur. Özellikle o dönemlerde ülkenin riskini iyi ölçemeyen, ülkenin kredi notunu yüksek tutan ve ülkeye yatırımı teşvik eden kredi derecelendirme kuruluşları bu kaynak aktarımların da önemli rol oynamıştır. Bunlar yanında ülkenin ödemeler bilançosunda ne† hata noksan kalemindeki artışlarının da gösterdiği üzere, bu dönemlerde ülkedeki karı değerlendirmek isteyen kayıt dışı girişlerde artmıştır. Bu süreçte ülkeye gelen kaynaklar milli geliri artırmış ve gelen yatııımların sürekli artması da ülkenin borçlanma iştahını kabartmıştır.

Ülkede o dönemlerde tasarruf oranları incelenirse, oranların milli gelirdeki artışa paralel olarak artmadığı da görülmektedir. Sonuçta dış kaynağa bağlı canlanma ve büyüme ülkede krizin patlak vermesi son bulmuştur. Kriz döneminde ülkeye ge- 
len yatıımlar ve sıcak para azalmıștır. Ülkeye gelen kaynaklarında ülkeden çıkmaya başlaması ülkedeki krizin daha da derinleşmesine neden olmuştur. Sonuçta da dış açıklarını finanse etmek için borçlanan Yunanistan ekonomisi çökmüştür.

Yunanistan'da yaşanan bu krizlerin atlatılabilmesi ve Avrupa Birliği'nin bundan zarar görmemesi adına, diğer kriz ülkelerinde olduğu gibi Almanya ve Fransa bu süreçte ülkelere yardım ellerini uzatmışlardır. Yunanistan'a verilen IMF ve AB kaynaklı krediler süreçte artmış, ancak artan borç yükü, üretimi düşük ülkenin bu kredileri geri döndürmesini imkânsızlaştırmış̧ır. Birlik ülkelerinin ekonomilerinin canlanması adına sürekli piyasaları fonlayan AB Merkez Bankası'nın (ECB), bu politikası euro-dolar paritesinin düşmesine neden olmuştur.

Birlik üyesi ülkelerin özellikle de Yunanistan'ın kurtarılmasına yönelik politikalar sürerken, son olarak Güney Kıbrıs' da bankacılık sektörünün çöküşü ile patlak veren kriz birliğin geleceğinin sorgulanması tartışmalarını artırmışıı. Öyle ki, Güney Kıbrıs'ta yaşanan krizin yıkıcı etkilerinin Yunanistan krizinden daha fazla olacağı düşünülmektedir. Güney Kıbrıs, kara para aklamanın ve vergilerde sağladıkları cazip koşullar nedeniyle, Rus sermayesine hizmet veren bir bankacllk sektörüne sahiptir. $A B^{\prime}$ nin ilkelerine ters olarak ülkeye gelen kaynağı korumak ve sürekliliğini sağlamak adına izlenen politikaların, Kıbrıs'ta yaşanan kriz sürecinin kaynağı olduğu düşünülmektedir.

Dış kaynakların ülkeye gelmesi aşamasında verilen taahhütlerin yerine getirilmesi için, Rum bankalarının büyük tutarlarda Yunanistan tahvillerini satın almak gibi riski büyük yatıımlar yapması, ülkede bankacılık sektörünün sonunu hazırlamıştır. Öyle ki, Yunanistan ekonomisinin finansal krize girmesi ile bu yatırımların geriye dönüşü güçleşmiştir. Ayrıca Rus sermayedarlarının kara para aklama merkezi haline gelen G. Kıbrıs'ın, $A B^{\prime}$ nin bu konudaki tavrını belli etmesiyle bu sermayeyi kaybetme tehlikesi ile karşı karşıya kalması da ekonomide krizin patlak vermesine neden olmuştur. 


\section{Euro Krizinin Öncesi ve Sonrasında Türkiye Ekonomi- sine Yönelik Bir Değerlendirme}

Son yllarda Avrupa'yı saran krizin Türkiye ekonomisi üzerine yansımalarına bakarken, Euro krizinin patlak verdiği dönemin öncesi ve sonrası diye ayırarak bakmak gerekmektedir. Gelişmekte olan ülke ekonomilerin en önemli gündem konularından birisi büyüme ve kalkınma hedeflerine ulaşmada sürekli karşılaştıkları cari denge sorunudur. Gelişmekte olan bir ekonomiye sahip olan Türkiye'de yıllardır süregelen cari açık sorunları ile uğraşmaktadır. Özellikle 2001 krizinin etkilerini üzerinden atarak, bu tarihten sonra büyüme sürecine giren ülkemizde cari açıklar küresel krizin patlak verdiği 2008 yllı sonrasına kadar sürekli artmışıır.

Tablo 1: Yıllar İtibariyle Türkiye Ödemeler Dengesi

\begin{tabular}{|c|c|c|c|c|c|c|c|c|c|c|c|c|c|}
\hline \multicolumn{14}{|l|}{ ÖDEMELER DENGESI ÖZET TABLO } \\
\hline (Milyon ABD Dolar) & 2002 & 2003 & 2004 & 2005 & 2006 & 2007 & 2008 & 2009 & 2010 & 2011 & 2012 & \begin{tabular}{|c|}
2012 \\
oca- \\
ağu
\end{tabular} & $\begin{array}{l}2013 \\
\text { oca- } \\
\text { ağu }\end{array}$ \\
\hline \multicolumn{14}{|l|}{ CARI İSLEMLER AÇIĞININ OLUŞUMU } \\
\hline ihracat & 40719 & 52394 & 68535 & 78365 & 93613 & 115361 & 140800 & 109647 & 120902 & 143396 & 163218 & 106299 & 107101 \\
\hline ithalat & -47109 & -65883 & -91271 - & -111445 & -134671 & -162213 & -193821 & -134497 & -177315 & -232535 & -228553 & -151731 & -161463 \\
\hline Dı̣s Ticaret Aç̣̆ & -6390 & -13489 & -22736 & -33080 & -41058 & -46852 & -53021 & -24850 & -56413 & -89139 & -65335 & -45432 & -54362 \\
\hline Diğer Döviz Geliri (Hizmetler+Gelir+Cari Transferler & 5764 & 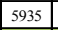 & 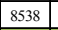 & 11631 & 9222 & 9071 & 12583 & 12682 & 10966 & 14047 & 17583 & 10081 & 10069 \\
\hline CARÍ IȘLEMLER AÇIĞI & -626 & -7554 & \begin{tabular}{|c|}
-14198 \\
\end{tabular} & -21449 & -31836 & -37781 & -40438 & -12168 & -45447 & -75092 & -47752 & -35351 & -44293 \\
\hline \multicolumn{14}{|l|}{ CARİ AÇIĞIN FINANSMANI } \\
\hline Yurticinde Dogrudan Yatirim & 939 & \begin{tabular}{|l|}
1222 \\
\end{tabular} & 2005 & 8967 & 19261 & 19941 & 17211 & 7110 & 7572 & 13698 & 8445 & 6875 & 5744 \\
\hline Portfoy Hesabi-Yukumlulukler & -593 & 2465 & 8023 & 13437 & 7415 & 833 & -5014 & 227 & 16093 & 21986 & 40789 & 19540 & 16860 \\
\hline Kredi & 826 & 3475 & 7674 & 20281 & 16013 & 28513 & 22533 & 2786 & 35396 & 31014 & 20516 & 23603 & 28310 \\
\hline SERMAYE GÍRIȘi & 1172 & 7162 & 17702 & 42685 & 42689 & 49287 & 34730 & 10123 & $|59061|$ & 66698 & |69750 & 50018 & 50914 \\
\hline Net Hata Noksan & -758 & \begin{tabular}{|l|l|}
4489 \\
\end{tabular} & 838 & 1964 & -228 & 517 & 3011 & 2879 & 1405 & 9433 & 867 & 2685 & 3016 \\
\hline TOPLAM DöVIZ GIRIȘí & 414 & 11651 & \begin{tabular}{|l|l|l|}
18540 \\
\end{tabular} & 44649 & 42461 & 49796 & 37680 & 12959 & 60415 & 76106 & 70573 & 52703 & 53930 \\
\hline CARII İșLEMLER AÇIĞII & -626 & \begin{tabular}{|l|}
-7554 \\
\end{tabular} & -14198 & -21449 & -31836 & -37781 & -40438 & -12168 & \begin{tabular}{|l|l|}
-45447 \\
\end{tabular} & -75092 & -47752 & -35351 & -44293 \\
\hline REZERVE EKLENEN DÖViZ & -212 & \begin{tabular}{|l|l}
4097 & \\
\end{tabular} & 4342 & 23200 & 10625 & 12015 & -2758 & 791 & 14968 & 1014 & 22821 & 17352 & 9637 \\
\hline
\end{tabular}

Kaynak: TCMB Veri Sistemi

Şekil 3'de, ülkemizde cari açıkların artmasındaki en önemli nedenin dış ticaret açıklarındaki artış olduğu görülmektedir. Türkiye'de dış ticaret açıklarının arkasında yapısal ve konjonktürel nedenler yer almaktadır. Türkiye yapı gereği ara malı ve yatırım mallarında dışa bağımlı bir ülke olmasının yanı sıra, enerji ve petrolü de yurtdışı kaynaklardan temin etmektedir. Dolayısıyla büyümek için sanayileşen ülkemizde üretimlerin artması ancak ithalatın artması ile olmaktadır. Ödemeler dengesine ilgill dö- 
nemlere bakıldığında ihracatımızın sürekli arttığı görülmekte iken, ihracatın ithalatı karşılama oranlarındaki düşüklük Türkiye'nin ithalatlarının daha fazla artmasına ve sonuçta dış ticaret açıklarının artmasına neden olmuştur. Cari işlemler açığının diğer alt kalemlerinde bu dönemlerde yaşanan pozitif bakiyeler, dış ticaret açıklarını kapatmaya yetmemiş ve küresel krizin patlak verdiği 2008 yılına kadar Türkiye'de cari işlemler açığı artmıştir.

2008 yllında patlak veren küresel krize kadar ülkemizde cari açığın finansman şekli için, öncelikle ödemeler bilançosunun diğer ana kalemi olan sermaye finans hesabındaki gelişmelere bakmak gerekmektedir. 2008 ylına kadar büyüyen Türkiye ekonomisinde bu büyümenin kaynağının, esas olarak bu dönemlerde ülkeye gelmesi için teşvik edilen sıcak para (portföy yükümlülükleri) ve özellikle özelleştirme gelirlerinin yansıdığı doğrudan yabancı sermaye yatıımları olduğu görülmektedir. Özet olarak 2008 yılına kadar ülkedeki karlı ortamı değerlendirmek için gelen dış kaynaklar sayesinde, Türkiye üretimini artırmış ve şekil 4'de de görüldüğü üzere bu dönemde büyüme oranları artmıştır.

Grafik 3: Yıllar İtibariyle Büyüme (199-2012) (\%)

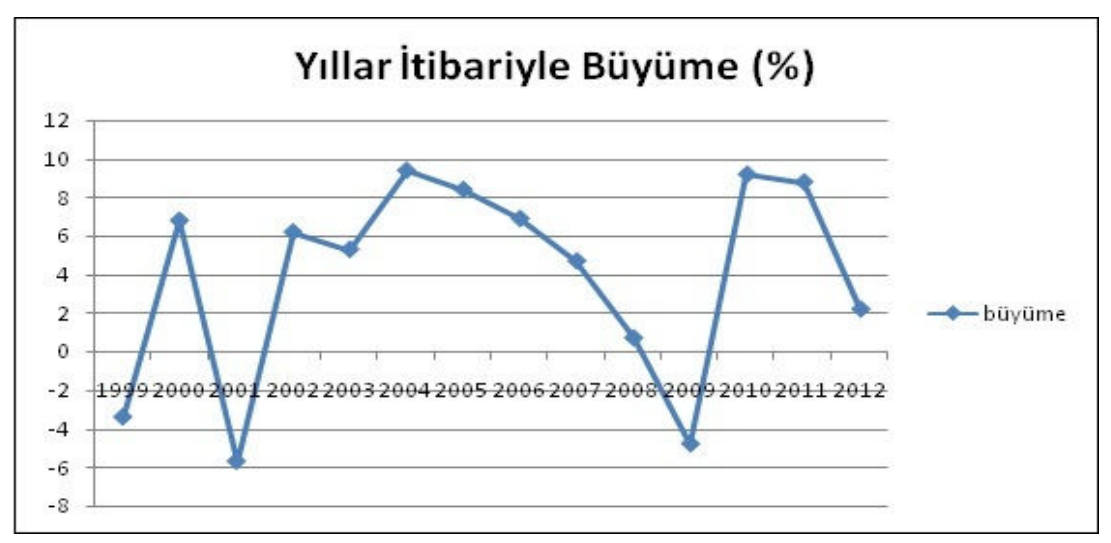

Kaynak: Hazine Müsteşarlığı Veri Sistemi

2008 ylında ABD'de patlak veren kriz tüm dünyayı bir anda sarmış ve tüm dünyada olduğu gibi Türkiye ekonomisini de 
etkilemiştir. 2008 ylında ülkeye gelen sıcak para (portföy yükümlülükler) çıkmış ve doğrudan yabancı yatııımlarda bu dönemde azalmıştır. Üretiminde dolayısıyla da ihracatında dış kaynakların önemini belirttiğimiz ülkemizde, bu kaynakların azalması ve ülkeden çıkmasının sonuçları özellikle 2009 yılında görülmektedir. Küresel krizle daralan dünya ekonomisinde yaşanan taleplerdeki azalma üretimimizi ve inracatımızı azaltmıştır. İhracatı ithalatına bağlı olan ülkemizde, ithalatların azalması sonucunda da 2009 ylında cari açığımız azalmıştır. 2008 yılında talep ve maliyet enflasyonunun arttığı ülke ekonomimiz, 2001 krizinden sonra ilk kez 2009 ylında küçülmüş (\%-5) ve işsizlik oranları ülkemizde artmıştır.

2008 ylında patlak veren ve tüm dünyayı etkisi altına alan küresel kriz, tüm dünya ülkelerinde olduğu gibi Avrupa ülkeleri de etkilenmiştir. Küresel kriz 2009 yllı ile birlikte $A B$ ülkelerini etkisi altına almış ve birlik üyesi birçok ülke bu dönemde finansal sorunlar yaşamıştır. Letonya, Macaristan gibi ülkelerle başlayan süreç, İrlanda da derinleşmiş ve 2010 yllında da Yunanistan krizi ile yeni bir borç krizi (EURO krizi) olarak adlandırımaya başlanmıştır.

Euro krizi ve $A B^{\prime}$ nin bu konuda atacağı adımlardaki belirsizlikler, özellikle Yunanistan ve benzeri Avrupa ülkelerine yatırım yapmış kişilerin bir anda bu ülkelerden çıkmasına neden olmuştur. Bu ülkelerden çıkan yatıımlar farklı ülkelere kaymış ve bu ülkelerden biride bu dönemde Türkiye olmuştur. Bu dönemde Türkiye'de hükümetin dış kaynakların ülke içine çekilmesi yönündeki teşvikleri de bu durumda etkili olmuştur. Bu durum şekil 3'deki ödemeler bilançosunda 2010 ylına bakıldığında çok net görülmektedir 2010 yllında Türkiye'ye gelen sıcak paranın görüldüğü hesap olan portföy yükümlülükleri hesabındaki artıs dikkat çekicidir. Aynı dönemde doğrudan yatıımlarında tekrar artışa geçmesi ile TL değer kazanmış ve döviz kurlarında düşüş yaşanmıştır. 2010 yılında döviz kurlarındaki azalma ile ithal girdi maliyetleri azalmış ve şekil 3'de de görüldüğü gibi ithalatımız bu dönemde artmışıır. İthalatımızdaki artışların inracatımızdaki artışlardan fazla olması ise, 2010 ylında dış ticaret açığımızın art- 
ması ile sonucunu doğurmuştur. Dolayısıyla 2008 küresel krizinin etkisi ile küçülen ekonomimiz, 2010 yılında gelen dış kaynaklar ile tekrar küresel kriz öncesi döneme dönerek büyüme sürecine girmiştir. Şekil 4'de de görüldüğü üzere 2009 ylında \% 5 küçülen ekonomimiz, 2010 yllında \% 9 oranında büyümüştür.

Özellikle doğrudan yabancı yatıımlar yoluyla dış kaynak girişlerinin arttığı 2011 yllında da ekonomimiz büyüme sürecini sürdürmüştür. Avrupa'daki kriz sürecinin getirdiği belirsizlikler ve dış kaynağa yönelik teşvik politikaları, ülkemize dış akımların olmasının en önemli nedenleridir. Ekonomideki kayıt dışı tutarların görüldüğü net hata noksan kaleminin de bu yıl içerisinde artış göstermesi, ülkemize gelen kaynaklara bağlı olarak üretimimiz ve ithalatımız artmışıı. Tüm bu gelişmeler ile beraber büyüme sürecindeki ekonomimizin, bu dönemde yüksek seviyede dış açık ve dolayısıyla cari açık vermesi beklenmeye başlanmışıır.

Yunanistan ve benzeri kriz ülkelerini kurtarmak adına Almanya ve Fransa önderliğindeki $A B$, bu ülkelere fon sağlamaya bu dönemde de devam etmiştir. Ekonomilerde artan euro miktarı, bu dönemde euro/dolar paritesinin düşmesine neden olmuştur. Düşen parite ise $A B^{\prime}$ nin ve para birliğinin geleceği konusunda yapılan tartışmaları artırmıştır. Özellikle ortak para ve merkez bankası kontrolündeki Yunanistan'ın euro'dan çıkarılması konusunda tartışmalar gündeme gelmiştir.

Avrupa'da süren bu tartışmalar ve euro/dolar paritesindeki düşüşler devam ederken, ülkemiz bu durumdan etkilenmeye devam etmiştir. Ülkemiz ihracatının önemli kısmını Avrupa ülkelerine ve euro karşılığı yapmakta iken, ithalatının önemli kısmını ise dolar olarak yapmaktadır. 2011 yllında ekonomide artan üretim, ihracat ve ithalat rakamlarına kur zararlarının da eklenmesi, bu dönemde oluşacak cari açığın aşırı olması endişesini yaratmıştır. Nitekim 2011 ylında Türkiye Merkez Bankası, yabancı para karşlllk oranlarında indirime gitmiş ve döviz ihaleleri yaparak piyasadaki dolar seviyesini artırmıştır. Bu şekilde artan kurlar tekrar istenilen seviyelere indirilmeye çalışısa da, 2011 ylında 
cari açığımız rekor kırarak yaklaşık 75 milyar dolar seviyelerine ulaşmıştır.

2011 ylı sonu ve 2012 ylı başında cari açık ile mücadelenin arttırıldığı ülkemizde, bu dönemde ihracatı teşvik politikaları artırımıştır. İhracatın desteklenmesi ile ithalatın belli seviyelerde tutulmasına yönelik çalışmalar neticesinde, bu dönemde dış ticaret açığımı ve dolayısıyla da cari açığımız düşmüştür. Bunların yanında 2012 yılında büyüme oranlarımızın da bir önceki ylın altında kalması ise, ekonomide bu dönem içerisinde cari açığa verilen önemin bir göstergesidir.

Avrupa'da Yunanistan krizi süreci devam ederken patlak veren Güney Kıbrıs krizinin Türkiye'yi nasıl etkileyeceği ise, Euro krizinin ülkemizdeki etkileri konusunda yapılan tartışmaların devam edeceğini göstermektedir. Güney Kıbrıs krizi ile birlikte, ülke ekonomisindeki Rus mevduatlarının Türkiye'ye kayması yönünde beklentiler oluşmuştur. Ancak, Rus devlet adamlarının Rus işadamlarına mevduatlarını Rusya'da değerlendirme çağıısı yapması nedeniyle bu durum pek olası görülmemektedir.

\section{Tahmini Rakamlarla Ekonomilere Genel Bir Bakış}

Euro bölgesi krizi devam ettiği sürece Euro bölgesi ve AB'nin geleceğine ilişkin sorular, gerek siyasi gerek ekonomik gündemin üst sıralarında tartışılmaya devam edecektir. AngloSakson geleneğinden bazı kesimler, Euro bölgesinin optimum bir para alanı olmadığı ve başarısız olmaya mahkum olduğu düşüncesiyle Euro karşı çıkmışlardır. Euro bölgesine dâhil ülke ekonomileri arasında önemli yapısal farkllıklar bulunduğundan, maliye politikalarında uyumlaştırma olmaksızın kurulacak bir parasal birliğin ülkeler arasındaki ekonomik dengesizlikleri daha da artıracağı ve parasal birliğin bozulacağı ileri sürülmüştür. UÇAR (2012).

Euro bölgesi oluşturulurken yapısal farkllıkların en aza indirilmesi için bir takım kriterler (Maastricht Kriterleri) belirlenmiş ancak, ilgili kriterleri sağlamayan ülkeler de birliğe dâhil edilmiş ve 
Euro kriziyle birlikte birliğin geleceği tartışlır hale gelmiştir. Euro krizinin geleceğine yönelik tartışmalarda, sorunun çözülmesi adına iktisadi paradigma çerçevesinde çözümler üretilmektedir. Buna göre üye ülkelerin ticari açıklarını azaltmaları, kamu borçlarını ve bütçe açıklarını yönetebilir düzeye indirmeleri gerekmektedir. ÖNIŞ ve KUTLAY (2012).

Grafik 4: 2013-2017 Yılları İtibariyle Ortalama Kamu Borç / GSYH Oranları

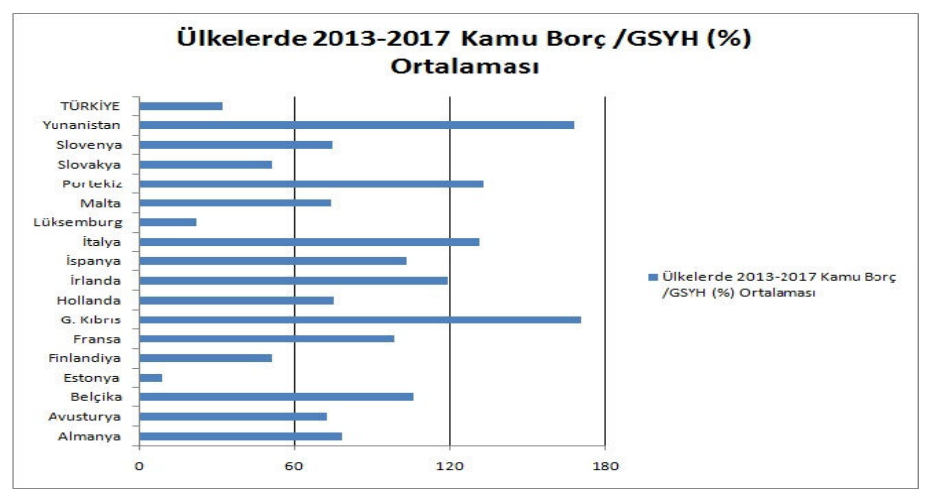

Kaynak: Eurozone, Eurostat, Hazine Müsteşarlığı, Orta Vadeli Program.

Maastricht kriterlerine göre üye ülkelerin kamu borçlarının GSYH'ye oranının \% 60'ı geçmemesi gerekmektedir. 2013-2017 döneminde tahmini rakamlara göre, Euro bölgesi ülkelerinin kamu borçlarının GSYH'ye oranları genel olarak artış seyri izlemiş ve ağırlıklı olarak ilgili kriterin dışında olan ülkelere Slovenya'da eklenmiştir. Şekil 2'de de görüldüğü üzere Slovenya kamu borç/ GSYH oranı \% 54 seviyelerindeyken, 2013-2017 döneminde yaklaşık ortalama \% 75 seviyelerine çıkmıştır. Krizin en çok etkilediği ülkelerden Yunanistan ve G.Kıbrıs ekonomilerinde de ilgili kriter daha da kötüleşmiş ve 2013-2017 döneminde yaklaşık ortalama sırasıyla \% 168 ve \% 170 seviyelerinde gerçekleşmiştir. Euro bölgesi ülkelerinde ilgili kriterin gelecekte daha da kötüleşmesi beklenirken, 2012 yllında Türkiye'de \% 36 seviyelerinde olan kriterin 2013-2017 döneminde ortalama \% 32 seviyelerine inmesi beklenmektedir. 
Grafik 5: 2013-2017 Yılları İtibariyle Ortalama Bütçe Açığı / GSYH Değişimi

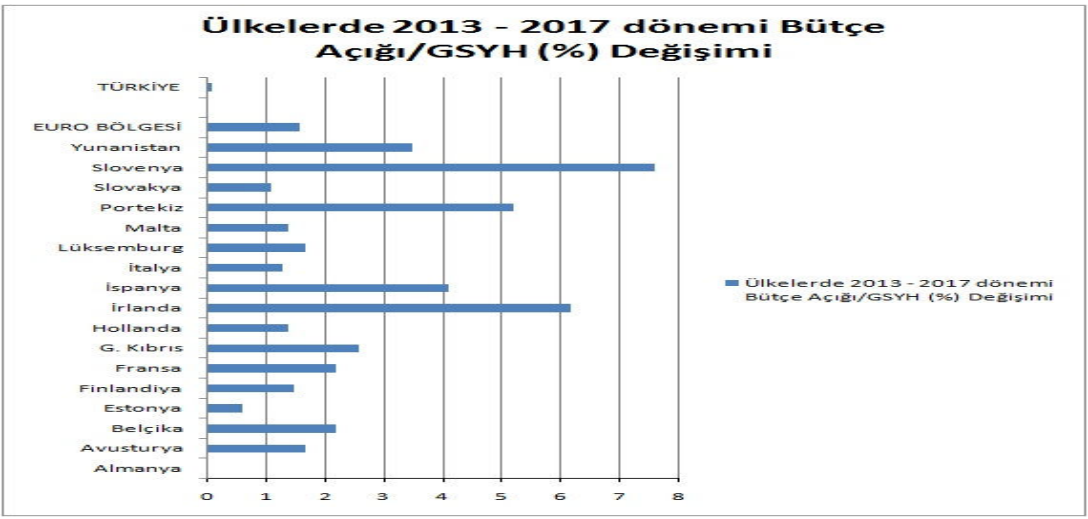

Kaynak: Eurozone, Eurostat, Hazine Müsteşarlığı, Orta Vadeli Program.

Maastricht kriterlerine göre \% 3 olması gereken bütçe açığı/ GSYH oranında, şekil 5'de de görüldüğü üzere 2013-201 7 döneminde genel olarak olumlu gelişmeler olması beklenmektedir. 2012 yllında ilgili kriterin \% 3'ün çok üzerinde olduğu ülkeler Yunanistan, İspanya, İrlanda gibi ülkeler dahil Euro bölgesi ülkelerinin genelinde, ilgili kritere yakınsama söz konusudur. Bununla birlikte 2013-2017 döneminde realize olması beklenen rakamlara göre, bütçe açığı/GSYH kriterinin olumsuz yönde gelişmesi beklenen ülkelerde bulunmaktadır. Nitekim 2012'de kriterin yaklaşık \% 4 olduğu Slovenya ile yaklaşık \% 4,9 olduğu G.Kıbrıs ekonomilerinde, 2013-2017 dönemlerinde kriter ortalamasının sırasıyla yaklaşık \% 4,7 ile \% 5,3 olması beklenmektedir.

Krizin çözümlenmesi için kamu açıklarının ve bütçe açıklarının azaltılması gerektiği savı dikkate alındığında, Euro bölgesi ülkelerinde bütçe açıklarının azalması yönündeki beklentiye rağmen kamu açıklarının artması beklenmektedir. Bununla birlikte Şekil'6 ya bakıldığında, 2013 yılı ve 2017 yılları arasında 